Revista Iberoamericana, Vol. LXXVII, Núm. 234, Enero-Marzo 2011, 135-148

\title{
DE DISCURSOS NÃO COMPETENTES A SABERES DOMINANTES: REFLEXÕES SOBRE AS HISTÓRIAS EM QUADRINHOS NO CENÁRIO BRASILEIRO
}

\author{
POR \\ WALDOMiro VERgueiro \\ GÊIsa Fernandes D’Oliveira
}

A formação e o estabelecimento dos saberes não éum processo natural. Informações que hoje tomamos por evidentes foram algum dia desconhecidas, mais tarde suspeitadas, talvez rechaçadas, até passarem, em alguns casos, de novidade a crenças estabelecidas conquistando um lugar em nossas enciclopédias e dicionários.

No decorrer de décadas, questões, antes reservadas ao foro íntimo transformaram-se em tema de debate em diferentes meios, conclamando a discussão pública. Do sufrágio universal, passando pela conquista de direitos trabalhistas, até as diversas bandeiras empunhadas por grupos específicos da sociedade (homossexuais, idosos, portadores de necessidades físicas), os embates sociais migram para múltiplas arenas, sem respeitar movimentos específicos. Num exemplo: cresce o número de mulheres que hoje lutam pelo direito de permanecer mais tempo em casa com os filhos recém nascidos, direção contrária ao caminho trilhado na década de 1970, quando uma das reivindicações mais freqüentes era a igualdade de tratamento no mercado de trabalho.

O locus social, portanto, só pode ser entendido se for considerado em seu caráter fluido, líquido (Bauman), no qual contornos não são claramente demarcáveis. Fazem parte desta definição as identidades que emergem das relações de poder, que se dissolvem e se reagrupam em torno de causas comuns, muitas vezes urgentes e, não raro, passageiras. Uma vez desfeito o elo gerado na tensão do embate, tanto pode haver um retorno às conformações anteriores, quanto a busca de novos caminhos. É o caso dos profissionais que assumem novas nacionalidades para concorrer a uma vaga, estudantes que trocam de passaporte para facilitar trâmites de viagem, refugiados políticos e de guerra que buscam asilo num novo país. Identidades mais ou menos temporárias, transportadas por sujeitos históricos e expressas por meio das diversas linguagens.

As considerações a seguir tratam do deslocamento das histórias em quadrinhos, durante o século $\mathrm{xx}$, de discursos não competentes ao rol dos saberes dominantes (Foucault). O foco no caso brasileiro permite a observação do processo de estabelecimento de uma linguagem e sua influência na formação de saberes. 


\section{FORMAÇÃO DE IDENTIDADES E PRODUÇÃO DE CONHECIMENTO}

O crítico literário brasileiro José Castello afirmou recentemente (2008) que a literatura “mira o que não se pode ver. E, por isso, ‘sofre’ do que tenta ver”. A declaração de Castello se volta para uma questão pertinente à representação: a contradição a que estão sujeitos os objetos representados, a um só tempo copiando e anulando seu original pois, ao recortá-lo para que caiba dentro dos limites do suporte, a representação deixa ainda mais evidente o que permanece do lado de fora. Ao eleger o que é representável, reinventa o objeto do qual partiu. Arealocação do objeto dentro da representação é também criação e, portanto, trato na realidade. Quando a fronteira entre a coisa representada e seu referencial parece ter se apagado, no momento em que a representação se torna um valor em si, novas abordagens, novos saberes são construídos. No processo de construção de identidades, por meio da representação, pode ser verificado o mesmo princípio que o sociólogo polonês Zygmunt Bauman reconhece na formação de um consumidor: "não é uma ação solitária ou uma realização definitiva. Começa cedo, mas dura o resto da vida” (73).

Como um produto, as identidades se desgastam, entram e saem de moda, apresentam “defeitos", tem de ser trocadas ou consertadas e nem sempre "caem bem" em quem as porta. A discussão, o embate, a zona de conflito formam o lar da identidade, seu habitat natural. Uma vez cessada a querela, apaziguadas as diferenças de maior grau, uma vez reunidos sob um mesmo guarda-chuva, os abrigados da tempestade das crises identitárias calam-se até que a tormenta passe, mas isso não significa que estejam mudos, nem a salvo de outras intempéries. Outros guarda-chuvas, por vezes menores - as identidades étnicas, de gênero, de orientação sexual-, por outras maiores - as identidades nacionais, ou supranacionais -, decerto precisarão ser inventados e abertos à hora certa.

Portáteis, as identidades são traduzidas em linguagens que, por sua vez, se dispersam em programas de cultura (Schmidt) diversos, os quais completarão a tarefa de fixá-los em saberes dominantes, em detrimento de outros: os saberes periféricos, discursos desqualificados, não competentes, de acordo com a nomenclatura de Michel Foucault. Os saberes dominados, segundo ele mesmo, compreendem: 1) conteúdos históricos que passam despercebidos em coerências funcionais ou em sistematizações formais e 2) série de saberes, previamente “desqualificados como não competentes ou insuficientemente elaborados: saberes ingênuos, hierarquicamente inferiores, saberes abaixo do nível requerido de conhecimento ou de cientificidade” (Microfísica 170), o saber das pessoas. Ao contrário do conhecimento, que privilegia o objeto, em detrimento do sujeito (Revel 77), o saber se define pela relação entre objetos do conhecimento e sujeitos que os apreendem. Ao qualificar o saber de enfermeiros e doentes, elevando seus discursos ao mesmo patamar da fala do médico; ao permitir o diálogo entre o delinqüente e quem o vigia, faz-se uma opção não por um saber unânime, comum, mas, ao contrário, por um saber particular, local, cuja força advém justamente de sua

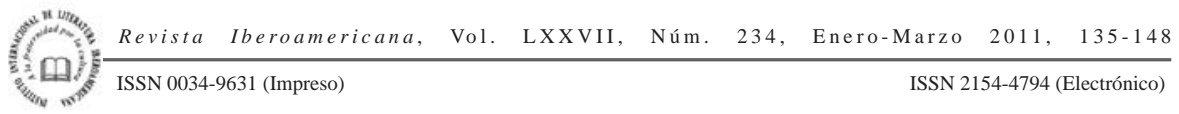


capacidade de sobrevivência, de manter-se em circulação, movimentando-se por entre as porosidades dos discursos oficiais.

Por meio da tática fragmentária de análise de discursos locais, pode-se reativar o combate mascarado por grandes massas de saber histórico reconhecido, qualificado, científico. O objetivo não é a oposição entre saberes e conteúdos, mas sim a negociação dos efeitos de poder que decorrem deste combate. Para tanto, há um retorno aos acontecimentos históricos, aos momentos de tomada de consciência das rupturas. Partindo da prática clínica e do estabelecimento do sistema carcerário, Foucault (Vigiar e Punir) chama a nossa atenção para o que há de historicamente construído, de não-natural nos encarceramentos e no tratamento reservado aos doentes mentais. No contingente revela-se o que é histórico.

O processo de abandono de um discurso pautado pela ordem vivenciado pelas sociedades contemporâneas no que diz respeito às artes, seu papel e, acima de tudo, seus objetos, modifica a maneira como os agentes sociais lidam com as linguagens. Os receptores são, também eles, produtores e as novas tecnologias reforçam a mistura de funções. Inscritos em uma sociedade disciplinar, agentes sociais atuam como difusores de saberes (Foucault, Vigiar). A sociedade da qual fazem parte os educou (e aqui não se trata apenas da educação formal escolar), os registrou, identificou seus gostos, catalogou suas produções e, a partir destas informações, se comunica com eles. E se a cultura está ligada às linguagens que a traduzem, também está ligada ao estabelecimento de saberes postos em prática a partir de estratégias de rompimento e de continuidade. Uma vez estabelecidos, os conteúdos geram efeitos de poder que marcarão as linguagens.

Uma reflexão acerca das histórias em quadrinhos no cenário brasileiro deve considerar a via de mão dupla entre real e representações do real. Equivale dizer: quais são os recursos dos quais o autor lança mão para, a partir de uma folha de papel em branco, desenvolver seus personagens, ações cenários e narrativas, construindo uma ponte de aproximação com a realidade. Os personagens de histórias em quadrinhos são intérpretes, atores de papel, que seguirão as regras de tipização das formas narrativas clássicas, daí o erro em considerá-los tipos estáticos, clichês (Grünewald 31). Representação e real não se alinham mais como um observador se postando em frente ao espelho, mas sim como irmãos siameses, de existências distintas, mas ligados entre si.

Ao se traçar um panorama das linguagens visuais que antecedem diretamente as histórias em quadrinhos, percebe-se que o interesse em torno delas cresce, não à medida que estas se tornam populares, mas sim quando conseguem se elitizar, se fechar num círculo ao qual as classes mais populares não têm acesso. A utilização de simbologia clássica, citações, referências extra-textuais, entre outros recursos, afasta o leitor vulgar, mas atrai a emergente camada burguesa que pode aplicar, no processo de decodificação das narrativas, a sua erudição (Grünewald). Portanto, a popularização (e o mesmo vale para retrações no seu consumo) de uma linguagem num meio diz respeito não só àquele meio, mas também às pessoas que o formam e seus parâmetros sócio-culturais.

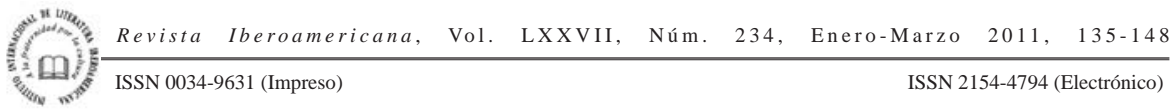


A este respeito, Álvaro de Moya afirma que a tira Blondie, de Chic Young, lançada em 1930, deve sua boa recepção ao fato de que muitos puderam se identificar com aquela família de classe média, vivenciando dificuldades pelas quais a grande maioria passava durante a Repressão. Além disso, a tira incorporou na personagem-título várias mudanças de gênero próprias do período. Em Blondie era possível não só reconhecer a dona-de-casa, mas também a mulher batalhadora e independente, "livre, mas esposa" (Moya 76). O público se aproxima da tira por conseguir se enxergar nela, que, por sua vez, tem neste mesmo público seus olhos, seu canal de ligação com os fatos que serão reproduzidos. Dos fatos que se apresentavam diariamente nos jornais, repetidos e pessimistas, surge uma narrativa que vai além do fato, que faz rir dele, que o reconstrói. A narrativa informa mais que o fato e vira, ela mesma, algo digno de nota. No entanto, as histórias em quadrinhos ocuparam durante muito tempo o espaço reservado a formas menos "sérias" de literatura.

No Brasil, essa tendência não foi diferente, como se pode verificar no comentário do jornalista e militante marxista Astrojildo Pereira no livro Crítica Impura: autores e problemas, publicado em 1963. As histórias em quadrinhos estariam no extremo oposto de seu projeto crítico de busca pelas raízes nacional-populares da cultura no Brasil e levariam ao embrutecimento e à deseducação da juventude (apud Cirne 12).

A fala de Pereira expõe as preocupações da época em relação à cultura brasileira. Ignorando um golpe militar às portas e ainda sob o impacto da Revolução cubana de 1959, a intelectualidade brasileira se dividia entre apoiar um modelo de revolução popular, nos moldes soviéticos, e afirmar o caráter autônomo de sua sociedade, rejeitando influências de países como os Estados Unidos, que se estabeleciam por meio da forte difusão de seus produtos, como referencial cultural e estético. Antecipando-se aos debates levantados mais tarde por outros movimentos de vanguarda, como o Tropicalismo, na música e o Concretismo na poesia e artes plásticas, Pereira deixava clara sua busca por um caminho próprio para a produção cultural brasileira. Seus temores encontravam respaldo na maciça difusão das publicações norte-americanas. Analisada à luz da bagagem acumulada por diversos campos do conhecimento, como a Lingüística e a Psicologia, a fala de Pereira carece de uma compreensão mas sutil das várias camadas de leitura que uma narrativa permite. $O$ meio não veicula apenas uma mensagem, nem serve aos interesses de apenas um grupo. As camadas de fruição de uma narrativa serão tão mais complexas e matizadas, conforme o leitor o permitir.

À idéia de uma forma de recepção inteiramente passiva, a narrativa das histórias em quadrinhos contrapõe uma necessidade de engajamento por parte do leitor, que deverá preencher os diversos espaços semânticos entre as calhas por meio do continuum virtual (Cirne 23), a capacidade da narrativa visual alimentar-se de algo que é a sua própria negação (o que não é visto). O corte, anunciando um movimento que acontecerá fora do quadrinho, preenche o vazio entre duas imagens com outras que não estão lá. O

Revista Iberoamericana, Vol. LXXVII, Núm. 234, Enero-Marzo 2011, $135-148$
ISSN 2154-4794 (Electrónico) 
continuum, apesar de ser um fenômeno que se processa na mente de cada observador, resulta de imagens coletivamente compartilhadas e apreensíveis não apenas por suas características mais aparentes. O caso dos super-heróis é bastante ilustrativo a este respeito. Tantas vezes apontados como porta-vozes de interesses estrangeiros, cumprem igualmente, junto aos jovens leitores, um papel semelhante ao dos personagens dos contos-de-fada. Independentemente de localização geográfica ou vestimenta, apresentam características identificadas em diversos grupos como desejáveis: a força descomunal, destreza e capacidade de resolver problemas de um jeito autoritário, porém reconhecido como positivo.

\section{O CASO BRASILEIRO}

A busca por um quadrinho autenticamente nacional não se inicia com as enfáticas palavras de Pereira e já estão mesmo presentes na gênese dos nossos quadrinhos, sob a forma de acentuada crítica política e de costumes, marcas registradas da caricatura, linguagem da qual os quadrinhos brasileiros herdaram muitas de suas características.

Coube justamente a um criativo e mordaz caricaturista, o ítalo-brasileiro Angelo Agostini, a autoria das primeiras narrativas em imagens seqüenciadas publicadas no Brasil (Cirne, História 16). Em As Aventuras de Nhô Quim, de 1869 (Figura 1), e As Aventuras de Zé Caipora, de 1883, Agostini calcava seu humor no confronto entre tipos urbanos e rurais. A Corte e suas afetações européias, as riquezas de fachada eram postas à prova por tipos como o homem do campo, próspero e simples ou o valente índio brasileiro.

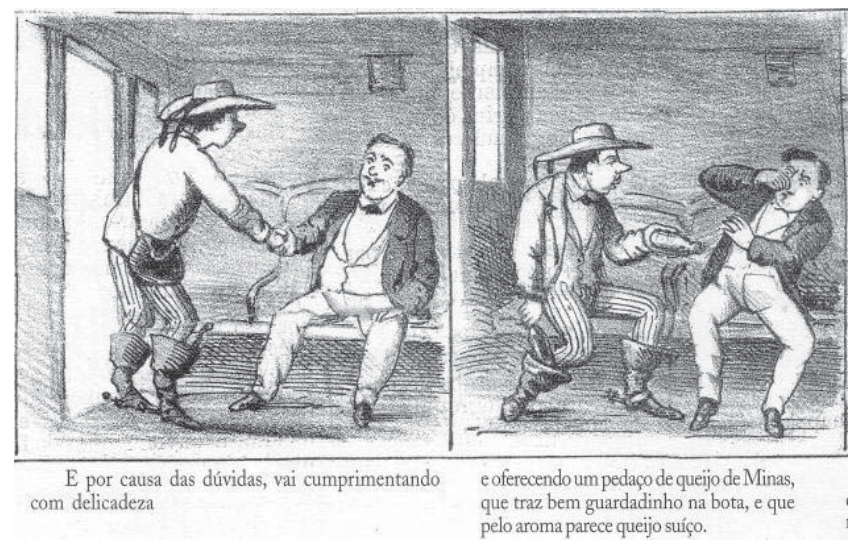

Figura 1 - Nhô Quim, de Angelo Agostini

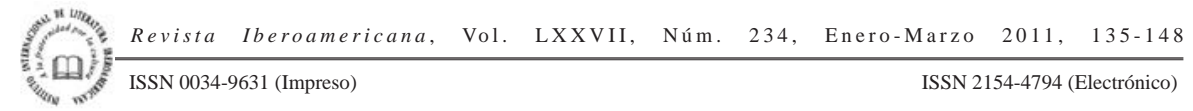


Embora pautada por grandes sucessos vindos do estrangeiro, o mercado nacional de quadrinhos não raro expressou uma preocupação em definir o conceito de brasilidade. A Revista O Tico-Tico (1905) exemplifica esta conduta: o célebre Chiquinho, carrochefe da publicação, na verdade Buster Brown, criação do norte-americano Richard Felton Outcault, era devidamente escoltado na publicação brasileira pelo amigo negro Benjamin, personagem não existente na história original, criado em terras brasileiras (Cirne, História 21; Vergueiro e Santos 16).

Ao longo do século xx, a relação entre quadrinhos nacionais e a busca de uma identidade nacional assumiram várias formas. Os anos 1930-40 consolidaram a veiculação e consumo de quadrinhos estrangeiros no país, com destaque para o Suplemento Juvenil, publicação de Adolfo Aizen. A Segunda Guerra Mundial aumentou o fascínio em torno da figura dos super-heróis. A reação da produção nacional viria a acontecer nos anos 1960, com a publicação da revista Pererê, de Ziraldo Alves Pinto e seu conteúdo declaradamente nacionalista. Na década de 1970, o cartunista Henfil lança personagens que se tornariam emblemáticos, como a Graúna, ambientada no sertão nordestino, e os irreverentes Fradinhos. Outra forma de resgate de valores tradicionais que perdiam terreno num país que se queria cada vez mais industrial foi desenvolvida por Mauricio de Sousa e os personagens da Turma da Mônica. Porém, após o golpe militar de $1^{\circ}$ de abril de 1964, que deu início a vinte anos de ditadura no país, a produção cultural brasileira tomou outros rumos.

O periódico humorístico $O$ Pasquim foi a grande publicação do período do regime militar brasileiro, destacando-se por uma postura nacionalista e crítica contra os desmandos dos poderes dominantes. Nela, sempre sob a vigilância das autoridades, questões importantes para a cultura brasileira eram discutidas e aprofundadas. Nesse sentido, pode-se dizer que a própria gênese da publicação guarda uma relação de contigüidade com a realidade do país, pois, segundo uma história corrente a respeito de sua fundação, a idéia de seu lançamento surgiu durante um encontro de amigos na praia de Ipanema, no Rio de Janeiro, espaço tornado famoso no mundo inteiro devido à composição musical "Garota de Ipanema", de Antônio Carlos Jobim e Vinícius de Moraes (um dos ícones brasileiros no exterior ao lado de Aquarela do Brasil, de Ary Barroso). Ali, reunidos em torno de garrafas de cerveja e admirando as mulheres em biquínis exíguos - tal como haviam feito Tom e Vinícius ao comporem "Garota de Ipanema..." -, o cartunista Jaguar propôs a seus companheiros de mesa Tarso de Castro, Sérgio Cabral e Carlos Prósperi o nome Pasquim, que foi aceito por todos, para um novo tablóide semanal de humor, que visava substituir A Carapuça, que pouco antes havia encerrado suas atividades.

O primeiro número chegou às bancas em 26 de junho de 1969. Era um semanário de crítica de costumes onde pouco espaço cabia ao comentário político aberto. [...] no começo não falavam quase nada de política, era uma publicação comportamental. Mas a

Revista Iberoamericana, Vol. LXXVII, Núm. 234, Enero-Marzo 2011, $135-148$
ISSN 2154-4794 (Electrónico) 
ditadura foi colocando o jornal contra a parede e, aos poucos, o Pasquim tornou-se mais e mais politizado. Na medida em que a censura aumentava, o Pasquim intensificava sua postura crítica. É da tradição do humor impresso a luta contra a opressão. Herdeiros de O Malho, A Careta, Dom Quixote, A Manhã e o Pif-Paf, jornais que em sua época não deram sossego ao governo. Os humoristas do Pasquim se sentiam na obrigação de se tornarem porta-vozes da indignação social brasileira. (Arbach 225)

O jornal durou 22 anos, encerrando-se em 1991. Por suas páginas passaram criações magistrais do humor nacional, mas seu grande momento criativo talvez esteja vinculado ao fato que levou, em 10 de novembro de 1970, à invasão da redação do jornal por um comando militar e à conseqüente prisão de toda sua direção: pouco antes, o jornal havia publicado uma sátira ao famoso quadro “Grito do Ipiranga”, do pintor Pedro Américo, principal símbolo da proclamação da Independência do Brasil. Na representação do momento máximo do processo de Independência do país de Portugal, o então príncipe herdeiro Dom Pedro é retratado de espada em punho e braço levantado às margens do riacho do Ipiranga, em São Paulo, no instante em que teoricamente bradou a expressão “Independência ou Morte!”, sinalizando para a decisão irrevogável em relação à liberdade do país. Nas páginas de $O$ Pasquim, o quadro é reproduzido, mas com um balão direcionado a Dom Pedro, contendo as palavras “Eu quero Mocotó” (Fig. 2). Na sátira, a proclamação histórica, símbolo da vontade do povo brasileiro, embora exarada pela boca do dominante, envereda para a crítica social, parecendo reproduzir a visão de governantes interessados em garantir vantagens pessoais, defendendo regalias e modelos estabelecidos de dominação social.

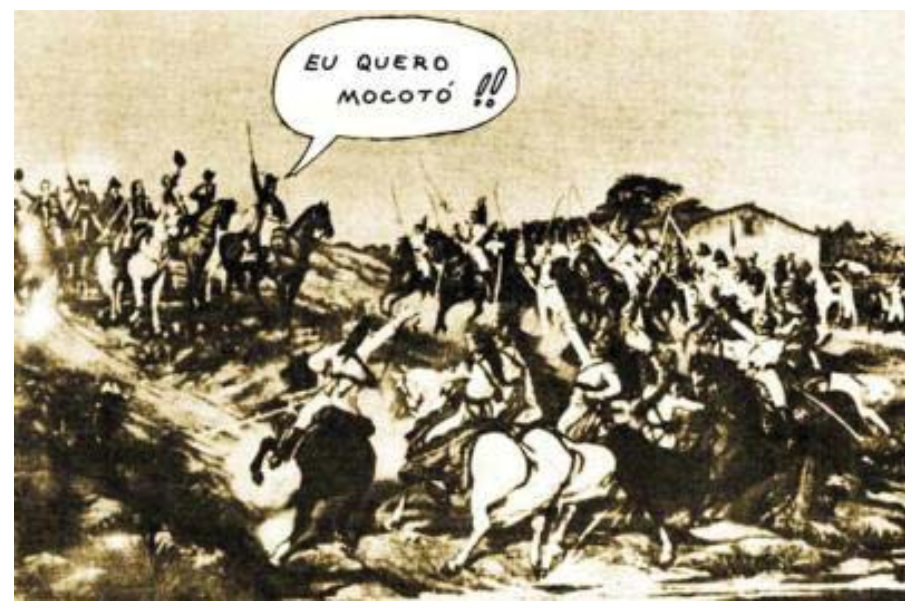

Figura 2 - Quadro de Pedro Américo satirizado no semanário Pasquim

Revista Iberoamericana, Vol. LXXVII, Núm. 234, Enero-Marzo 2011, $135-148$
ISSN 2154-4794 (Electrónico) 
Outras criações de humor da publicação seguiam na linha de reforço à brasilidade. Henfil, por exemplo, ali postou o Cabôco Mamadô, personagem negro que criticava aqueles contrários às posições do autor, principalmente relacionadas com a defesa da cultura brasileira; Fortuna desenhou o surreal Madame e seu bicho muito louco, e Os Zeróis, de Ziraldo, que contrapunham aos heróis norte-americanos versões satíricas, refletiam características da realidade brasileira.

Outra iniciativa importante na área de quadrinhos ocorrida no período da ditadura foi a revista Crás, publicada pela editora Abril, de São Paulo. Empreendimento ousado, lançado em 1974, visava responder às dificuldades vividas pelos quadrinhistas brasileiros e pela indústria editorial. Foi idealizada pelo escritor e editor Cláudio de Souza, funcionário da empresa que, naquele momento, dirigia as edições infanto-juvenis da Abril. A publicação trazia uma mescla de estilos gráficos e de gêneros, com quadrinhos de terror, de humor, de aventura, infantis etc., compostos por artistas de tendências mais variadas. As histórias enveredavam pelo estilo clássico, pelas tiras de aventuras norteamericanas e pelo experimentalismo psicodélico da década de 1970. Entre esses autores destacam-se Renato Canini, com Kactus Kid; Carlos Edgard Herrero, com Lobisomem; e Ruy Perotti, com Satanésio.

Kactus Kid era uma paródia dos filmes de faroeste norte-americanos, com seu protagonista sendo, na verdade, o agente funerário Zeca Funesto, que precisa colocar peruca ruiva e dentadura, bem como fazer um furinho no queixo para se transformar no pistoleiro Kactus Kid (Fig. 3). O protagonista veste-se como um caubói tradicional, trazendo lenço no pescoço, colete, chapéu alto, botas e cinturão com cartucheira. A introdução às histórias do herói já deixa clara a intenção satírica e demitificadora: "Amado pelas mulheres! Invejado pelos homens! Temido pelos bandidos! Perseguido pelos... credores! Assim é... Kactus Kid”.

Lobisomem (Fig. 4), criado por Edgar Herrero em parceria com o roteirista Júlio Andrade Filho, tinha suas histórias ambientadas em um burgo europeu durante a Idade Média, sendo protagonizadas por um Homem-Lobo que não consegue assustar e atacar suas vítimas. Satanésio (Fig. 5), por sua vez, era um diabo - ou, melhor dizendo, um pobre diabo - que deixa o inferno (ambiente falido por causa da violência e dos desentendimentos que caracterizam a sociedade) e vem para a Terra em busca de melhoria de vida. Porém, Satanésio encontra apenas pessoas intransigentes, desonestas e brutais, que absolutamente não sentem qualquer medo dele.

Também na década de 1970 merece menção o surgimento dos títulos de revistas de histórias em quadrinhos da Turma da Mônica, que desde essa época permaneceram ininterruptamente nas bancas de jornal. Mauricio de Sousa começou a publicar esses títulos pela Editora Abril e posteriormente, na década de 1980 transferiu-se para a Editora Globo. A última mudança ocorreu em 2007, quando os títulos passaram a ser publicados pela multinacional Panini. A nova casa permitiu a criação de novos projetos, com relançamento de tiras antigas e o desenvolvimento de novos produtos,

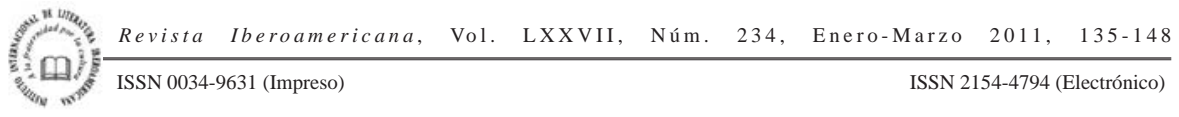



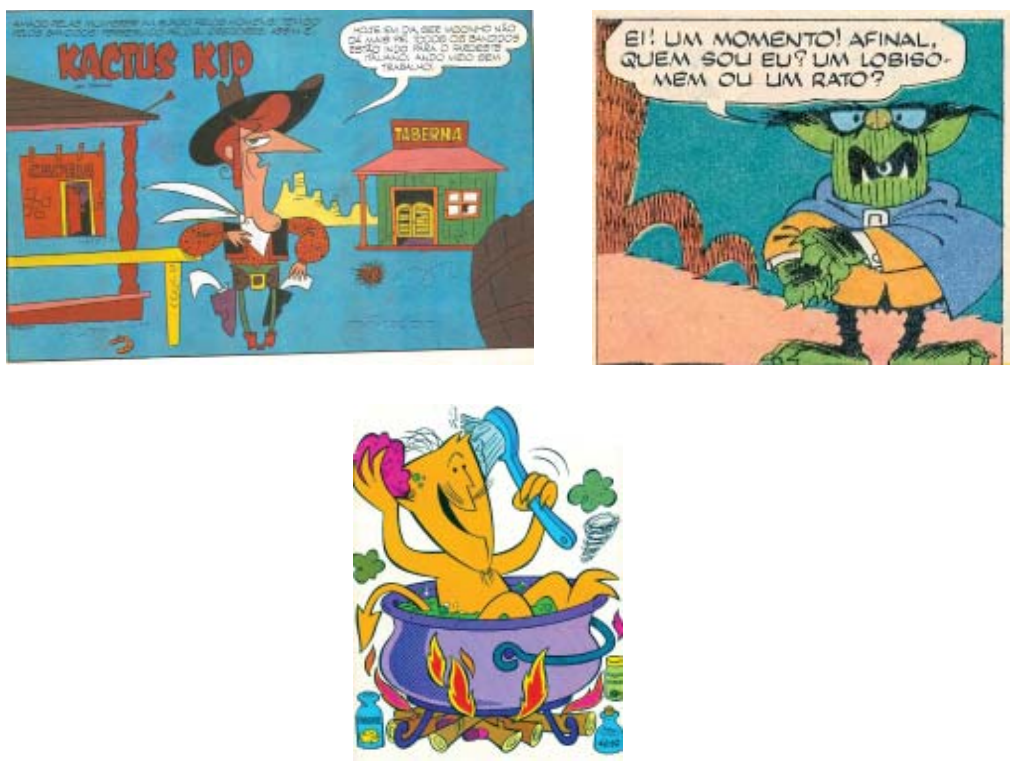

Figuras 3, 4 e 5 - Personagens marcantes da revista Crás

como minisséries e uma versão adulta dos personagens da Turma da Mônica. Este projeto, intitulado Turma da Mônica Jovem, caracteriza-se, no panorama quadrinhístico brasileiro, como uma das mais ousadas iniciativas editoriais deste século, retratando os personagens da Turma da Mônica em sua adolescência. A proposta quer atingir o leitor que já não é mais criança e que tende a abandonar as revistas infantis mensais. Ao mesmo tempo, o título buscou se colocar como uma alternativa para a produção de quadrinhos japoneses, que desde a virada do século passaram a ser vendidos de forma acentuada nas bancas brasileiras, atraindo a atenção de grande parte dos leitores. Desta forma, Mauricio e sua equipe de criadores preparam um material com temáticas apropriadas ao público escolhido e elaboram um produto com características semelhantes às dos quadrinhos procedentes do Oriente - decisão editorial amplamente divulgada nas capas das revistas e em matérias promocionais, identificando os novos produtos como tendo sido elaborados "em estilo mangá".

Lançado oficialmente em agosto de 2008, durante a Bienal Internacional do Livro de São Paulo, Turma da Mônica Jovem (Fig. 6) atraiu um grande público ao evento, curioso a respeito da nova caracterização dos famosos personagens de quadrinhos. Colaborou para isso a intensa penetração midiática em volta do lançamento, da qual participaram redes de televisão, jornais e revistas de entretenimento, todos divulgando e disseminando a imagem dos conhecidos personagens, agora em nova roupagem. Essa

Revista Iberoamericana, Vol. LXXVII, Núm. 234, Enero-Marzo 2011, $135-148$
ISSN 2154-4794 (Electrónico) 

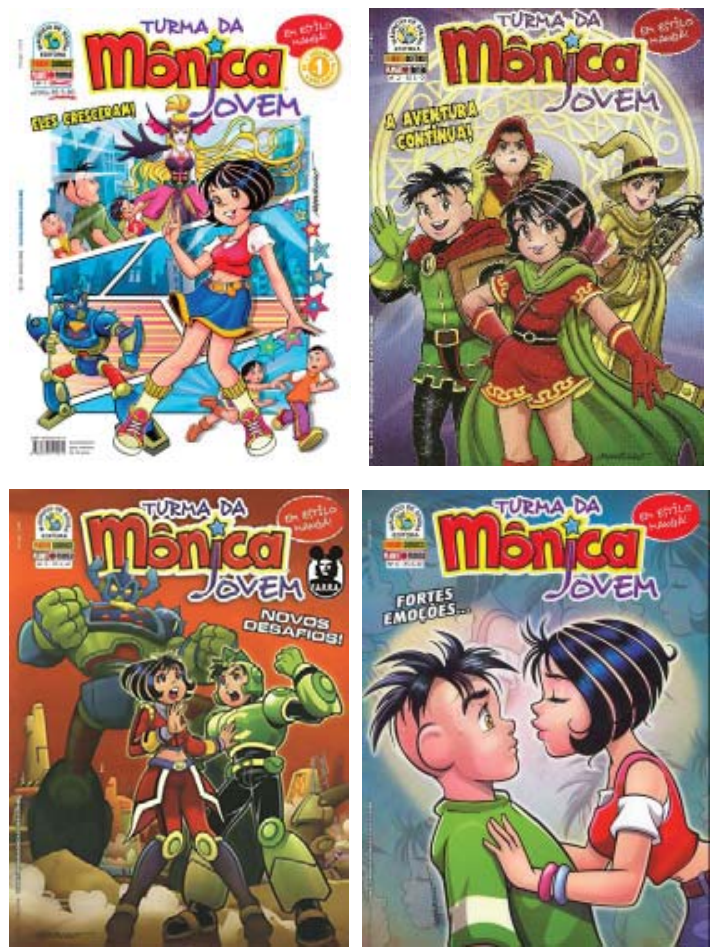

Figura 6 - Capas da revista Turma da Mônica Jovem

cobertura da mídia não se restringiu apenas ao lançamento, mas persistiu nos meses seguintes e também no início de 2009, com o autor sendo seguidamente convidado a entrevistas em espaços nobres da mídia. Algumas manchetes de jornais e portais da Web são especialmente contundentes:

Turma da Mônica ficará adolescente na versãoe em mangá(Site Blog dos Quadrinhos, 12/06/2008)

Turma da Mônica entra na adolescência (Site Portal Correio, 15/06/2008)

Personagens da Turma da Mônica cresceram (Portal UAI, 02/07/2008)

Mônica vai ficar com Cebolinha (O Estado de São Paulo, 12/07/2008)

Mônica e seus amigos agora são adolescentes e vão encarar os conflitos típicos da idade (30/07/2008)

Turma da Mônica vira teen em nova HQ (Folha Online, 04/08/2008)

A Turma da Mônica cresceu. Como assim? (Portal UOL, 05/08/2008)

Dentuça, sim. Baixinha e gorducha, nunca mais (Correio Popular, 17/08/2008)

$\begin{array}{llllll}\text { Revista Iberoamericana, Vol. LXXVII, Núm. 234, Enero-Marzo 2011, } & 135-148 \\ \text { ISSN 2154-4794 (Electrónico) }\end{array}$ 
Turma da Mônica envelhece e chega à adolescência (Cosmo Online, 17/08/2008) Mônica e Cebolinha se beijam em nova fase da turma (Globo Online, 28/11/2008)

Estratégias empresariais de marketing mas que, além disso, navegam por águas de um espectro cultural mais amplo: o de uma cultura pop globalizada que incorpora e visa permitir diferentes e complexas leituras da mesma narrativa. Assim, se os jornalistas e profissionais de marketing destacaram na iniciativa os aspectos sensacionalistas, vistos sob a égide do mercado, os estúdios Mauricio de Sousa tomaram o cuidado de ter acesso às críticas veiculadas na empresa e também levantadas pelos leitores em sites de relacionamento como o Orkut. Parte dos aspectos negativos levantados nas primeiras edições foram modificados nos números seguintes. Um exemplo foi a reavaliação do nome do personagem Anjinho, batizado inicialmente como Céuboy na versão adolescente. No quarto número de Turma da Mônica Jovem, ele foi re-batizado de Ângelo (Fig. 7). Esse estranhamento em relação ao nome do personagem foi uma das críticas levantadas pela imprensa e pelos leitores.

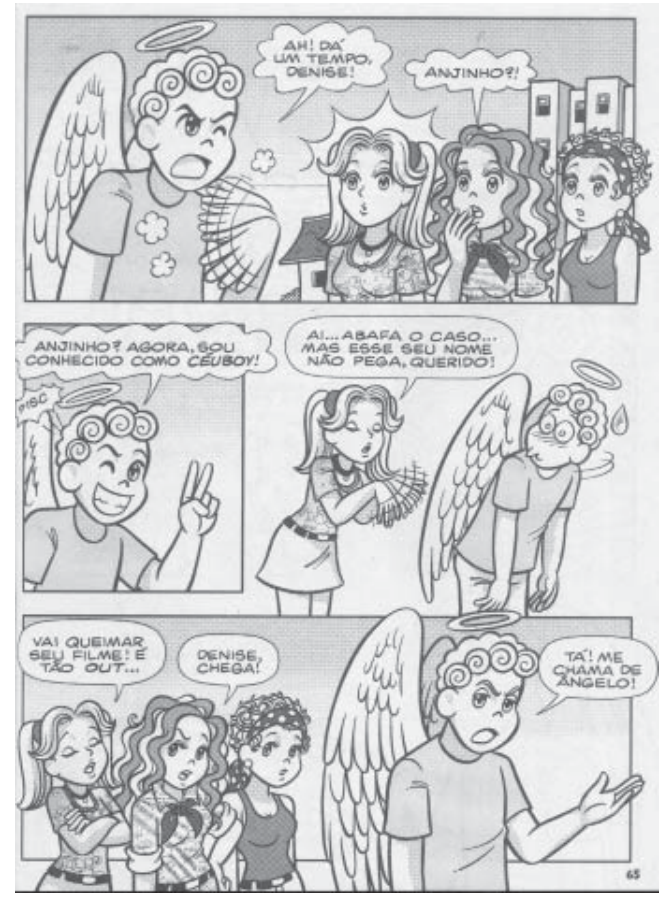

Figura 7 - Página da revista Turma da Mônica Jovem n. 4

Revista Iberoamericana, Vol. LXXVII, Núm. 234, Enero-Marzo 2011, $135-148$
ISSN 0034-9631 (Impreso) 


\section{CONCLUSÃO}

O panorama da produção de quadrinhos no Brasil pode ser usado como uma via de entendimento do processo de inclusão do país em discussões estéticas (no que se refere à forma), econômicas (fatores referentes à produção e circulação dos exemplares) e políticas (temas mais freqüentes, grau de liberdade de produção, dentre outros) de apelo internacional.

A historiografia do presente, nos moldes foucaultianos, resgata o que parece sem história: o acontecimento rejeitado, o acontecimento antes da identidade discursiva. A ruptura, a porosidade que permite o procedimento original, o método timidamente novo de aproximação com objetos inéditos a tornam uma prática adequada para a problematização da linguagem das histórias em quadrinhos. A realocação destas no panorama da discussão estética atual provoca uma reconfiguração dos discursos das belas artes e seus cânones. Em outras palavras: o caminho que leva um discurso nãocompetente em direção ao reconhecimento se dá por meio de um movimento simultâneo entre objetos e formas de análise. Os produtores culturais desempenharão o papel de críticos de suas próprias obras.

O aumento do número de trabalhos sobre histórias em quadrinhos na academia (Vergueiro e Santos) e até mesmo seu emprego em exames de admissão para as diversas universidades brasileiras são provas do estabelecimento da linguagem como forma de compreender o real. O discurso dos quadrinhos se “qualifica”, obtém “competência” para ser usado como mediador de realidades, na medida em queé visto pelo pesquisador como fonte primária, assim como ocorre com a produção de outras linguagens (a fotografia, a telenovela, o romance).

O termo "saber dominante" não significa nem uma crença de que o discurso das histórias em quadrinhos tenha se sobreposto a outros, nem que dispense a interação com outras linguagens, mas uma alteração, ao mesmo tempo sutil e determinante. $\mathrm{O}$ movimento de realocação de saberes e o estabelecimento de discursos nos permitem descobrir muito a respeito do que as sociedades entendem por ciência, seus sistemas de crenças e relações de poder. Os objetos sobre os quais se debruçam o saber instituído mudaram, por certo, mas não foram os únicos. Mudou igualmente o olhar que os agentes sociais lançam sobre ele.

Saberes dominantes precisam enfrentar o desafio da historicidade. A expansão e diferenciação dos suportes responsáveis pela divulgação de histórias em quadrinhos trazem novas questões ao campo: se a tira e a caricatura não perdem seu frescor na forma impressa ou digitalizada até que ponto uma história interativa, somente disponível na internet, na qual o leitor escolhe o andamento e os desfechos da narrativa ainda é uma história em quadrinhos? O quão indispensáveis para este discurso são as calhas, os enquadramentos e mesmo o contato tátil, o virar de páginas? Quais as conseqüências para o autor do aumento do número de pessoas que terão acesso à obra e dos canais de

Revista Iberoamericana, Vol. LXXVII, Núm. 234, Enero-Marzo 2011, $135-148$
ISSN 2154-4794 (Electrónico) 
veiculação? Como suprir todos os sites especializados, além das versões on line de jornais e revistas? O quadrinista se vê obrigado a pensar a sua obra na mesma velocidade em que esta é consumida e a resposta, explícita ou não, será forçosamente mais imediata, influenciando sua produção futura.

A troca de informações entre elaborador e receptor que se verifica atualmente terá, decerto, desdobramentos que não conseguimos perceber por conta de nossa contemporaneidade. Entretanto, é possível afirmar que, a partir destas alterações, outras apreciações se estabelecerão e talvez o panorama da produção nacional daqui a algumas décadas guarde poucas semelhanças com o cenário atual. Mudaremos nós, agentes culturais e o mesmo acontecerá com nossas produções, como exemplifica a relação entre quadrinhos e cinema: se antes a sétima arte emprestava recursos narrativos à composição das histórias em quadrinhos (Cirne, Para Ler) agora delas se serve para arejar seus roteiros e sua narrativa e os quadrinhos foram elevados ao posto de nona arte. Por outro lado, menos provável é o retorno do discurso das histórias em quadrinhos ao rol dos discursos não competentes. Uma vez qualificados, os discursos se preservam em si mesmos e nas interfaces com as linguagens. Cabe a nós, sujeitos, fazê-los dialogar.

\section{REFERÊNCIAS}

Arbach, Jorge M. I. O fato gráfico: o humor gráfico como gênero jornalístico. São Paulo: Escola de Comunicações e Artes, 2007 [Tese de Doutoramento - Ciências da Comunicação].

Bauman, Zygmunt. Identidade. Entrevista a Benedetto Vecchi. Rio de Janeiro: Jorge Zahar, 2005.

Castello, José. “A Crítica como aventura”. O Globo, Caderno "Prosa e Verso”. 7 jun. 2008. 4.

Cirne, M. Para Ler os Quadrinhos - Da narrativa Cinematográfica à Narrativa Quadrinizada. Petrópolis: Vozes, 1975. História e Crítica dos Quadrinhos Brasileiros. Rio de Janeiro: FUNARTE, 1990. Quadrinhos, Sedução e Paixão. Petrópolis: Vozes, 2000.

Foucault, Michel. Vigiar e Punir: nascimento da prisão. Petrópolis: Vozes, 1987. Microfísica do Poder. São Paulo: Paz e Terra, 2004.

Grünewald, Dietrich. Vom Ungang mit Comics. Berlin: Volk und Wissen Verlag, 1996. Moya, Álvaro de. História das histórias em Quadrinhos. São Paulo: Brasiliense, 1996. Revel, Judith. Foucault: Conceitos Essenciais. São Carlos: Clara Luz, 2005.

Schmidt, Siegfried. Kalte Faszination-Medien, Kultur, Wissenschaft in der Mediengesellschaft. Göttingen: Hubert \& Co., 2000.

Vergueiro, Waldomiro. La historieta latinoamericana. Tomo III: Brasil. Buenos Aires: La Bañadera del Cómic, 2008.

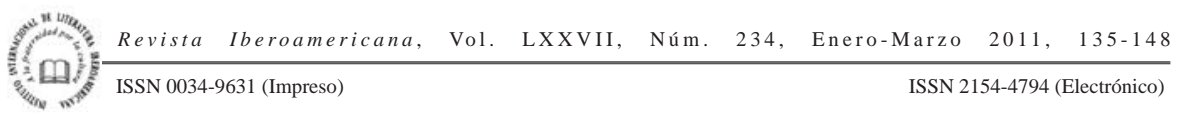


e Roberto E. Santos. “A pesquisa sobre histórias em quadrinhos na Universidade de São Paulo: análise da produção de 1972 a 2005”. UNIrevista I/3. <http://www. unirevista.unisinos.br/_pdf/UNIrev_VergueiroSantos.PDF>. 14 feb. 2009.

Revista Iberoamericana, Vol. LXXVII, Núm. 234, Enero-Marzo 2011, $135-148$
ISSN 0034-9631 (Impreso) 